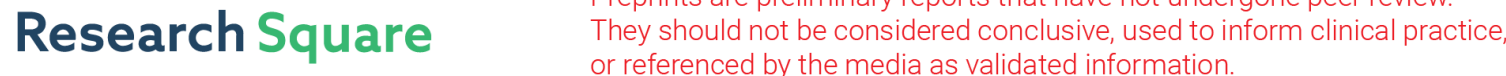

\section{Proteomic Profiling of Du145 Cell Line Exosomes Identifies Icam1 as Aputative molecular Mechanism by Which Relb Promotes The proliferation, Migration, and Invasion of Prostate cancer Cells}

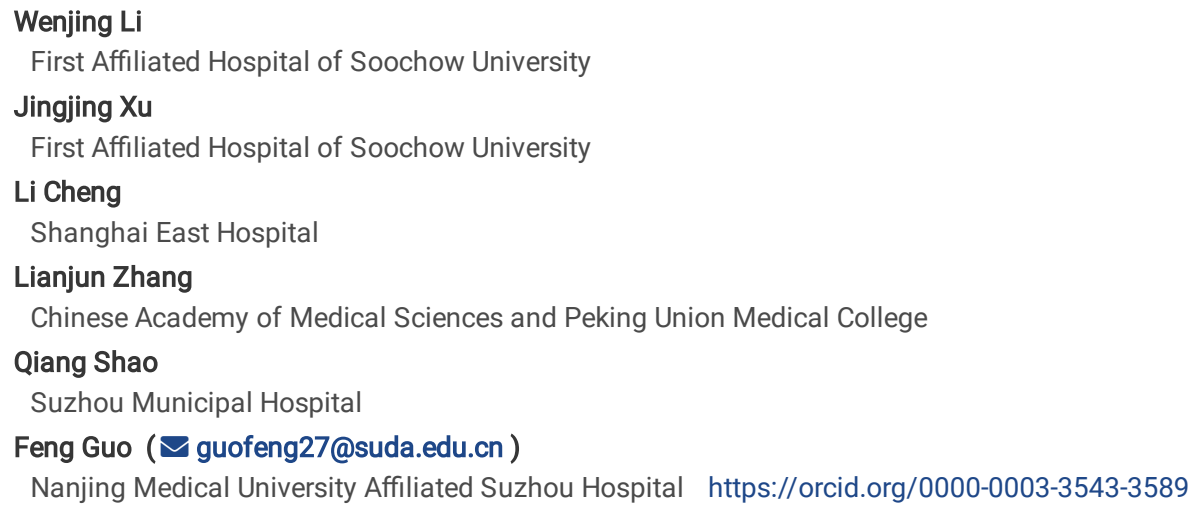




\section{Abstract}

Background: Prostate cancer (PC) is a serious health issue in men. Exosome plays essential roles in modulating the oncogenesis and progression of PC. RelB is highly expressed in PC and plays oncogenic parts in DU145 cells. We aim to uncover the protein panel of exosomes derived from RelB-knockdown DU145 cells (siRelB) as compared to control cells (sictrl) and explore a potential mechanism that RelB conferring the more aggressive phenotype to DU145 cells.

Methods: Exosomes derived from sictrl and siRelB were subjected to Liquid Chromatography-Mass Spectrometry for proteomics profiling. Label-free quantification strategy iBAQ (intensity-based absolute quantification) was used to quantify and Fold Change (FC) was calculated to identify the differentially expressed proteins (DEPs). The characterization of proteins was conducted by bioinformatics analysis. ICAM1 over-expressing DU145 cells (hICAM1) and control cells (hctrl) were established by transfection using Lipofectamine 2000. The cell growth, migration, and invasion capabilities were measured by the xCelligence real-time monitoring system. Annexin V/PI-staining was adopted to assess apoptosis. CCK-8 assay was applied for proliferation evaluation. Integrin $\beta-1$, MMP9, and uPA were detected by Western blot.

Results: 1259 exosomal proteins were identified, with 160 and 105 proteins unique to the siRelB and sictrl, respectively, while 994 proteins were present in both. We identified 137 upregulated and 55 downregulated proteins in siRelB. Gene Ontology (GO) analysis revealed that some DEPs had the cell adhesion molecular activity and participated in the cell adhesion process. Kyoto Encyclopedia of Genes and Genomes (KEGG) enriched that intercellular adhesion molecule-1 (ICAM1) was downregulated targeted by the NF-KB signaling. The FC of exosomal ICAM1 was 2.136. The expression of ICAM1 was positively related to RelB in PC by UALCAN. ICAM1 was shown to be co-expressed with RelB by GeneMANIA. The protein abundance of exosomal ICAM1 was lower in siRelB. hICAM1 had enhanced abilities of proliferation, migration, and invasion, with higher expression of Integrin $\beta-1$ when compared to hctrl.

Conclusions: Our study identified 192 exosomal DEPs downstream of RelB in the DU145 cells. Exosomal ICAM1, conferring a more aggressive phenotype to DU145 cells, is a potential molecular mechanism modulating the tumorigenesis and progression of PC cells.

\section{Background}

It is estimated to have 191,930 new cases of prostate cancer (PC) in the USA in 2020. The predicted death caused by PC could be 33,330 [1]. Though great progress has been made in illuminating the roles of various factors during the tumorigenesis and progression process, the exact mechanism is not yet fully understood. Tumor microenvironment (TME), the "soil" on which tumor cells live, play a critical part in the development and progression of a tumor. The exchange of substances or messages between cells is an important form of communication between members of TME.

Released by cancer cells or other members in TME, exosomes, the vesicles endocytosing various biological molecules, such as protein, DNA fragment, mRNA and miRNA via lipid bilayer containing membrane protein, are the crucial mediator of intercellular communication, playing important roles in tumorigenesis and advancement of cancer cells [2-4]. Exosomes derived from DU145 prostatic cells fairly promote tumor cell proliferation and migration, and reduce apoptosis in LNCaP and RWPE-1 cells [5]. Exosomes secreted by metastases-initiating cells support continued cancer growth and progression though activating RANKL, C-Myc, and FOXM1, which create a more inclined metastasis microenvironment for PC [6]. It has been proved that tumor-derived exosomes can be uptaken by specific organs or cells, to create favorable TME for cancer metastasis. For example, miR-21, miR-141, and miR-375 enriched exosomes derived from PC play important roles in assisting tumor cells to acclimatize to the low-androgen environment of distant metastatic organs [7].

RelB is the primary member in the non-canonical Nuclear factor $\mathrm{K}$-light-chain-enhancer of activated B cells (NF-KB) pathway, participating in the development and progression of multiple tumors [8-10]. RelB has been shown to correlate with the tumorigenesis, development, and radio-sensitivity of PC. In PC tissues, the expression of RelB is highest among all the NF-KB family members and directly related to the Gleason score, implying that RelB acted in the occurrence and development of PC. Suppressing RelB expression in malignant androgen-independent PC-3 cells greatly decreases the occurrence and proliferation of tumors [11]. Similarly, highly expressed RelB is associated with a more aggressive phenotype in androgen-independent DU145 cells. RelB-knockdown prominently attenuates the migration and invasion of the DU145 cells, because of the decrease of integrin $\beta-1$ [12]. RM1 cells transfected with the RelB-siRNA have an enhanced radio-sensitivity at various dosage points by clonogenic growth assay [13]. HZ08 could enhance the radio-sensitivity of PC cells through inhibiting PI3K/Akt/IKKa signaling pathway, leading to the down-regulation of MnSOD transcriptionally by keeping RelB from nuclear translocating [14].

NF-KB has been shown to regulate the secretion of substance inside exosomes [15]. However, exosomes from the RelB-knockdown DU145 cells have not been addressed. It is important to explore the roles of key molecules regulated by RelB during the tumorigenesis and advance of PC cells. In this study, we have identified several candidate exosomal proteins downstream of RelB, using Mass Spectrometry (MS) technique. Of note, we found that exosomal ICAM1 expression might play important parts in modulating PC proliferation and aggressiveness, overexpression of ICAM1 will strengthen the abilities of cell proliferation, migration, and invasion of DU145 cells.

\section{Materials And Methods}

\section{Establishment of RelB-knockdown cell line}

DU145 cell line was bought from ATCC (American Type Culture Collection). The cells passaged 2-5 times were used in our experiments. The cell line was certified using Short Tandem Repeat (STR) profiling (Shanghai Biowing Applied Biotechnology Company). All cell lines were routinely tested for mycoplasma. The RelB silenced DU145 cell line (siRelB) and control cell line (sictrl) had been established in a previous study [12]. Briefly, the shRNA-RelB (targeted gene 275293: 5'-GCACAGATGAATTGGAGAT-3') was synthesized and cloned into the pSilencer3.1-H1-neo vector (cat no. 5770, Thermo Scientific ${ }^{\text {TM }}$, USA). The pSilencer3.1-siRelB and the control plasmids were afterward transduced into cells by Lipofectamine 2000 (cat no. 12566014, Thermo Scientific ${ }^{\text {TM }}$, USA) following the instructions. The cells were cultured in the presence of $400 \mathrm{ng} / \mu \mathrm{l}$ neomycin (cat no. E859-5G, Amresco) for about 15 days. 


\section{Cell culture and supernatant collection}

DU145-siRelB and DU145-sictrl cells were maintained in RPMI-1640 media added with 10\% exosome-depleted fetal bovine serum (EXO-FBS-50A-1, SBI, Japan), $100 \mathrm{U} / \mathrm{ml}$ penicillin, and $100 \mathrm{\mu g} / \mathrm{ml}$ streptomycin at $37^{\circ} \mathrm{C}$ in a humidified atmosphere containing $5 \% \mathrm{CO}_{2}$. After the cell confluence reached $85 \sim 95 \%$, the culture medium was collected and stored at $-80^{\circ} \mathrm{C}$ after centrifugation at $500 \mathrm{~g}$ for $15 \mathrm{~min}$.

\section{Exosomes extraction and characterization}

Exosomes from exo-free FBS supernatant of both siRelB and sictrl were isolated by ultracentrifugation. Firstly, dead cells and large cell debris were deposited by centrifugations at $1200 \mathrm{~g}$ for $20 \mathrm{~min}$ and $10,000 \mathrm{~g}$ for $20 \mathrm{~min}$. Pellets from each centrifugation step were discarded. $100 \mathrm{ml}$ medium was collected and ultracentrifuged at $100,000 \mathrm{~g}$ at $4{ }^{\circ} \mathrm{C}$ for $90 \mathrm{~min}$ (Optima XPN-100 ultracentrifuge, Beckman, USA). The sediment was resuspended in $1 \mathrm{x}$ PBS for further analysis. The morphological characteristics of exosomes were confirmed by transmission electron microscopy using the method described by Ying et al [16]. Particle size by NanoSight analysis was conducted to verify the uniformity of microvesicle extracted.

\section{Exosome protein extraction, quantification, and immunoblotting}

The protein of exosomes was extracted using a 5x RIPA buffer with $1 \mathrm{mM}$ proteinase inhibitor. The mixture was vortex blended and cracked for 20 min on ice. The supernatant was collected after centrifugation at $10,000 \mathrm{~g}$ for $12 \mathrm{~min}$. The BCA assay was used for measuring protein concentration (Thermo Fisher Scientific, USA). The absorbance at $562 \mathrm{~nm}$ was determined. We drew the standard curve according to the calibrated absorbance value and standard concentration. The concentration of protein samples was calculated based on the standard curve. $20 \mu \mathrm{g}$ protein of exosomes were loaded on a $10 \%$ SDS gel for electrophoresis, followed by transfer to a polyvinylidene fluoride membrane. Primary antibodies used were rabbit monoclonal anti-human flotillin (cat no. 18634, Cell Signaling Technology, Germany), mouse monoclonal anti-human CD81, and mouse monoclonal anti-human CD63 (cat no. NB100-65805 and NBP2-42225, Novus Biologicals, USA). Goat anti-mouse IRDye 800cw secondary antibody and goat anti-rabbit IRDye 680 secondary antibody (cat no. 92632210 and 926-32221, Li-COR Biosciences, USA) were used as secondary antibodies. The image was scanned by Odyssey's two-color infrared fluorescence imaging system (Li-COR Biosciences, USA).

\section{Sample Preparation for Mass Spectrometry}

The exosome samples were cracked in buffer with $8 \mathrm{M}$ urea, 1\% Triton X-100, $65 \mathrm{mM}$ dithiothreitol (DTT, sigma, Germany), and $0.1 \%$ proteinase inhibitor (cocktail) using a high-intensity ultrasonic machine (JY99-IIDN, Scientz, China) on ice. Pellets were discarded after centrifugation at $5000 \mathrm{~g}$ for $3 \mathrm{~min}$ at $4{ }^{\circ} \mathrm{C}$. The pre-cooled $15 \%$ trichloroacetic acid was used to dissolve the protein for $2 \mathrm{~h}$ at $-20^{\circ} \mathrm{C}$. Protein precipitation was obtained after centrifugation at $15000 \mathrm{~g}$ for $10 \mathrm{~min}$ at $4{ }^{\circ} \mathrm{C}$, followed by three washing steps with cold acetone, dried for $5 \mathrm{~min}$ and subsequently rehydrated in buffer containing $8 \mathrm{M}$ urea, $100 \mathrm{mM}$ triethylamine-carbonic acid buffer (TEAB, pH 8.0). The BCA assay was used to determine protein concentration. Add 10 mM DTT (Sigma, Germany) into 100 $\mu \mathrm{g}$ protein samples at $37^{\circ} \mathrm{C}$ for $1 \mathrm{~h}$, then $20 \mathrm{mM}$ IAA (iodoacetamide, Sigma, Germany) were added for alkylation reduction at room temperature for 45 min. First enzymatic hydrolysis of protein samples was conducted at the present of $1 \mu \mathrm{g}$ trypsin at $37^{\circ} \mathrm{C}$ for $4 \mathrm{~h}$, followed by second enzymatic digestion with another $1 \mu \mathrm{g}$ trypsin at $37^{\circ} \mathrm{C}$ for $12 \mathrm{~h}$. Peptide mixture was acidized with $5 \%$ formic acid, demineralized using $\mathrm{C} 18$ spin columns, and eluted by $200 \mu \mathrm{l} 50 \mathrm{mM}$ $\mathrm{NH}_{4} \mathrm{HCO}_{3}$, then quantified and lyophilized.

\section{Liquid Chromatography-Mass Spectrometry (LC-MS) Procedure}

The procedure of LC-MS was referred to the instructions described by Zou et al [17]. The peptides were resuspended in $100 \mu$ l solvent A (A: water containing $0.1 \%$ formic acid; B: ACN containing $0.1 \%$ formic acid), separated by nanoLC and analyzed by on-line electrospray tandem mass spectrometry. The tests were conducted on a set of equipment including an EASY-nLC 1000 system (Thermo Fisher Scientific, Waltham, MA), an Orbitrap Fusion mass spectrometer (Thermo Fisher Scientific, San Jose, CA), and an online nano-electrospray ion source. $2 \mu$ peptide sample was loaded onto the trap column (Thermo Scientific Acclaim PepMap C18, $100 \mu \mathrm{m} \times 2 \mathrm{~cm}$ ), with a flow of $10 \mu \mathrm{l} / \mathrm{min}$ for $3 \mathrm{~min}$ and subsequently separated on the analytical column (Acclaim PepMap C18, $75 \mu \mathrm{m}$ $x 25 \mathrm{~cm}$ ) with a linear gradient, from $2 \%$ B to $45 \%$ B in $180 \mathrm{~min}$. The column was re-equilibrated at initial conditions for $5 \mathrm{~min}$. The column flow rate was maintained at $300 \mathrm{nl} / \mathrm{min}$. The electrospray voltage of $2.0 \mathrm{kV}$ versus the inlet of the mass spectrometer was used.

The Orbitrap Fusion mass spectrometer adopted a data-dependent mode for data collection by the alternative switch between Mass Scan (MS) and tandem MS (MS/MS) [18]. In MS scan, the ions with 350-1600 m/z and a charge state of $>3$ were chosen for deeper fragmentation in an orbitrap mass analyzer. The maximum ion introduction times were $50 \mathrm{~ms}$ for the full MS scan and $150 \mathrm{~ms}$ for MS/MS. The resolution were targeted as 120,000 (m/z, 200) for MS and $15,000(\mathrm{~m} / \mathrm{z}, 200)$ for MS/MS. The automatic gain control (AGC) were set as $5 \times 10^{5}$ and $2 \times 10^{5}$ for MS and MS/MS, respectively. Fragmentation was conducted to the ions in $+2,+3,+4$, or +5 charge state, with a minimum intensity threshold of 20,000 . Precursor ions were fragmented in a mode of higherenergy collisional dissociation (HCD) at $30 \%$ of normalized energy in the fracture pool. One Microscan was recorded employing a dynamic exclusion of 48 sec all the time.

\section{Identification of differentially expressed proteins (DEPs)}

Raw MS data were analyzed by Maxquant database (version 1.5.3.30) and retrieved using the integrated Andromeda search engine with a search strategy of target- decoy. The peptide designation was conducted by running raw data against the SwissProt-Human data set (Release 2017-04-10) (total of 20259 entries). Trypsin (Promega, Madison, WI) was used for specific digestion, and a maximum of 2 missed cleavages was permitted. The mass tolerance for fragment ions and precursor ions were $0.02 \mathrm{Da}$ and \pm 10 ppm, respectively. Carbamidomethylation of cysteine was set as a fixed modification. Protein $\mathrm{N}$ terminal, O-GIcNAc protein modification, or lysine carbamidomethylation, methionine oxidization were set as variable modifications. False discovery rate (FDR) 
thresholds set for peptide, protein, and modification sites were all 1\%. For protein identification, minimum peptide length was set as 7 amino acids with fewest one match of unique peptide.

The label-free quantification strategy iBAQ (intensity-based absolute quantification) was applied to quantify. The raw data were further processed by Perseus software. Protein group LFQ intensities were log2 transformed. The missing values were replaced by random values in the Gaussian distribution below the median to simulate low abundance LFQ values. Fold change (FC) filtering and Student's $t$ test were performed to screen DEPs between two groups by using the R software. DEPs were identified if the minimum matched unique peptide $>=1$, with a threshold $p<0.05$, absolute value of FC $>1.25$ and the FDR correction $<=0.05$. Venn diagram, volcano plot, and hierarchical clustering were performed for the DEPs of the two groups.

Gene Ontology (GO) analysis and Kyoto Encyclopedia of Genes and Genomes (KEGG) pathway enrichment were implemented to understand the exact characters and functions of DEPs. A p-value of less than 0.05 was considered enriched significantly. Three biological repeats were performed in the two groups.

\section{UALCAN database and GeneMANIA analysis}

UALCAN is a web portal integrating and analyzing cancer data based on The Cancer Genome Atlas (TCGA) database, providing plots and graphs describing gene expression and clinical prognosis according to sample type, race, age, or other factors [19]. In the present study, we used UALCAN to interrogate the correlation between RelB and ICAM1 and the expression of the ICAM1 gene in PC patients. GeneMANIA is an online tool processing protein-protein interaction (PPI) network, and giving information about physical interaction, gene co-expression, gene co-location, gene enrichment analysis, and website prediction [20]. We predicted the interaction between RelB and ICAM1 and generated the networks through GeneMANIA.

\section{Construction and verification of hICAM1 and hctrl cell lines}

The ICAM1 overexpressed cell line (hICAM1) and control cell line (hctrl) were established by transfecting pCMV3-ICAM1-His plasmid (cat no. HG10346-CH, Sino Biological Inc., China) and negative control vector (cat no. CV015, Sino Biological Inc., China) into DU145 cells with Lipofectamine 2000 reagent (cat no. 12566014 , Thermo Scientific ${ }^{T M}$, USA). Cells were maintained in the culture medium containing $400 \mathrm{ng} / \mu \mathrm{l}$ hygromycin (Roche Diagnostics GmbH, Germany) for two weeks. RNA was extracted using TRIzol (cat. no. 15596-026, Invitrogen life technologies, USA) method according to the instruction. RT-qPCR was conducted to test the ICAM1 mRNA expression in different clones and exosomes, using the following primers; forward primer, $5^{\prime}$ -

TCCGGCGCCCAACGTGATTC-'3, and reverse primer, 5'-CGGGGGCCATACAGGACACG-'3. The expression was normalized to $\beta$-actin (5'-

GCTACGAGCTGCCTGACGG-3' for forward primer, and 5'-TGTTGGCGTACAGGTCTTTGC-3' for reverse primer). $\triangle$ Ct was the Ct difference between ICAM1 and $\beta$-actin of each sample. $2^{-\triangle \mathrm{Ct}}$ was calculated to show the relative expression of ICAM1. Western blotting was applied to detecting the ICAM1 protein expression in cells or exosomes. Rabbit polyclonal anti-human ICAM1 (cat no. 4915, Cell Signaling Technology, Germany) was used as the primary antibody. The concentration of soluble ICAM1 (sICAM1) in exosome was measured using ELISA (cat no. DCD540, R \& D systems, USA), and calculated based on the optical density (OD) at $450 \mathrm{~nm}$. GraphPad Prism 6.0 was used to plot.

\section{Description of the biological characters of cell lines}

The cell growth, migration, and invasion activities were dynamically monitored by the xCelligence RTCA instrument (Roche) as described before [12]. In the cell growth assay, cells were planted at 7000 per well. The monitoring was last for $80 \mathrm{~h}$. A CIM 16-plate was used in cell migration assay, equipped with an upper and lower chamber. Cells were seeded at 40, 000 per well suspended in $30 \mu$ pure RPMI-1640 in the upper chamber, while $170 \mu l$ complete media was loaded into the wells of the lower chamber. Wells on the upper chamber pre-coated with matrigel were used for the cell invasion assay. 60,000 cells were seeded. The cell index was continuously monitored for $30 \mathrm{~h}$ for migration or invasion assay. CCK-8 assay (cat. no. ab228554, Abcam, England) was used to assess cell proliferation. Briefly, 6000 cells suspended in $100 \mu$ culture medium were planted into 96-well plate with quintuplicate wells per sample. Three wells added with $100 \mu$ l culture medium were used as blank control. The 96 -well plate was continued to incubate for $2 \mathrm{~h}$ after adding $10 \mu \mathrm{l} \mathrm{CCK-8}$ reagent. The OD values at $450 \mathrm{~nm}$ were measured at $24 \mathrm{~h}, 48 \mathrm{~h}$, and $72 \mathrm{~h}$. AnnexinV and PI dyes were adopted to analyze the early apoptosis using flow cytometry. $1.5 \times 10^{5}$ cells suspended in 3,000 $\mu \mathrm{l}$ complete medium were planted into a 6-well plate with triplicate wells per sample. Cells were harvested and stained using annexin- $\mathrm{V}$, $\mathrm{PI}$ or both for $15 \mathrm{~min}$ in darkness according to the instructions (cat. no. 40302ES50, Yeasen Biotech, China). The early apoptosis proportion was analyzed at 24 h, 48 h, and 72 h. The protein level of metastasis-related proteins integrin $\beta-1$, MMP9 (cat no. 4706 and 13667, Cell Signaling Technology, Germany) and uPA (cat no. sc-59727, Santa Cruz Biotechnology, USA) were analyzed by western blotting. The image was scanned by Odyssey. The data were analyzed and plotted using GraphPad Prism 6.0.

\section{Results}

\section{RelB affected the proliferation, migration, and invasion of DU145 cells}

In a previous study, we have demonstrated that the expression of RelB was higher in the DU145 cells when compared to the LNCaP and PC3 cell lines (Supplementary Figure 1A). We have also assessed the effect of RelB knockdown on the cell growth, migration, and invasion abilities of DU145 cells [12]. As the results showed (Supplementary Figure 1), the cell growth, migration, and invasion were markedly slower in siRelB cells than those in sictrl cells during the $72 \mathrm{~h}$ or $24 \mathrm{~h}$ persistent monitoring (all $p<0.05$ ). The in vitro scratch assay revealed that siRelB cells migrated to the scratch center much slower than sictrl cells at $72 \mathrm{~h}$. The protein level of integrin $\beta-1$ was decreased in RelB knockdown cells.

\section{Quality assessment of exosomal protein samples}


Transmission electron microscopy (Figure 1A) and NanoSight assay (Figure 1B) displayed that particles separated by ultracentrifugation contained tremendous DU145-derived EVs with a diameter of 30-150 nm. Immunoblotting revealed that exosomal samples were positive for protein markers CD63, flotillin, and CD81 (Figure 1C). To characterize the proteins in exosomes from sictrl and siRelB cells, proteomics profiling was performed by MS technique. Totally 1,259 proteins were identified through quantitative analysis. Results of consistency analysis between samples within the group showed that the $\mathrm{R}^{2}$ among the three biological repeats were all above 0.99, indicating excellent consistency among the protein samples (Supplementary Figure 2). 89.4\% $(1,125 / 1,259)$ proteins were recorded in Exocarta database (Figure 1D). The protein samples had a better purity and were qualified for proteomic profiling.

\section{Total proteome expression analysis}

Among the 1,259 proteins, 994 proteins were present in both sictrl and siRelB cell lines. 105 proteins and 160 proteins were unique to sictrl and siRelB, respectively, as shown in the Venn diagram (Figure 2A). Among the common 994 proteins, the canonical exosome proteins could be identified [21], exemplified by heat shock proteins (HSP90 and HSP70), endosomal molecules (clathrin), cytoskeletal proteins (actin, tubulin, and myosin), multivesicular tetraspanins (CD63 and CD81), antigen presentation molecules (MHC class I), adhesion proteins (integrins), immunoglobulin family members (ICAM1/CD54), and membrane trafficking proteins (RAB proteins and annexins). Regardless of the different groups, the iBAQ averages of exosomal proteins of the six samples were analyzed. The percentage of protein was calculated by the mean iBAQ value of individual protein divided the sum of calibrated iBAQ values of 1,259 proteins in the proteinGroups. The top 25 proteins accounting for $56.21 \%$ of the total exosome proteome were summarized and the expression proportion of each protein in both groups was labeled in Figure 2B.

\section{Recognition of differentially expressed proteins (DEPs) between sictrl and siRelB cells}

FC was calculated based on protein expression ratio of siRelB to sictrl cells [mean (iBAQ_siRelB) / mean (iBAQ_sictrl)]. Basing on the following criteria, the absolute value of FC $>1.25$, meanwhile $P \leq 0.05$ and FDR correction $\leq 0.05,192$ DEPs were identified, showed by hierarchical clustering (Figure $3 A$ ). The logarithm of FC (expressed as logFC) and the minus logarithm of $P$-value (expressed as -log $(P$-value $)$ ) were used to perform the volcano plot. Compared with the sictrl cells, 137 proteins were upregulated and 55 proteins were downregulated in the siRelB cells. As the 13 proteins and 26 proteins solely expressed in sictrl and siRelB cells couldn't be shown in the volcano plot (Figure 3B), we performed another heat map analysis (Figure 3C).

\section{Functional explore by GO enrichment of the DEPs}

To further characterize the DEPs, we investigated the functions of PC derived exosomal proteins through GO analysis. All the proteins were inputted to DAVID for the enriched cellular component, biological process, and molecular function terms at a cutoff of $p<0.05$. Microsoft Excel (version 2018) was used for plotting. The most populated exosomal proteins of the cellular component were cytoplasm, exosomes, and nucleus, the biological processes were mainly concentrated on signal transduction, protein metabolism, and cell communication; and the most dominant molecular functions were extracellular matrix structural constituent, chaperone activity and catalytic activity (Supplementary Figure 3A, 3B and 3C). Enrichment analysis of the 13 and 26 DEPs solely expressed in sictrl or siRelB were summarized in Table 1.

\section{KEGG pathway analysis of the DEPs}

Pathways enriched with the DEP were performed by the KEGG database. 9 pathways were enriched significantly based on the cutoff of $P$-value $<0.05$ (Supplementary Figure 4A). Supplementary Table 1 summarized the DEPs involved in the individual pathways. Shown in the map of the Epstein-Barr virus infection pathway (Supplementary Figure 4B), transmembrane protein ICAM1, a molecule regulated by the non-canonical NF-KB signaling, was downregulated in the siRelB cells (marked in a black rectangle).

\section{Bioinformatics characters of differentially expressed exosomal ICAM1}

Among the 192 DEPs, ICAM1 was downregulated in the absence of RelB, with an FC of 2.136, and $p$-value $<0.001$. GO analysis displayed that, ICAM1 was mainly derived from the plasma membrane, cytoplasm, exosomes, and extracellular space. ICAM1 exerted predominantly the functions of cell adhesion molecule activity, cell communication, and signal transduction; and principally participated in cell communication and signal transduction processes. Importantly, exosomal ICAM1 was found to be regulated by NF-KB signaling in the Epstein-Barr virus infection pathway by KEGG enrichment (Supplementary Figure 4B).

To investigate the relationship between RelB gene and ICAM1 gene, we viewed the correlation item of RelB gene in PC on UALCAN website. According to the TCGA database, among the top 24 genes positively correlated with RelB, ICAM1 ranked second, with a Pearson correlation coefficient as 0.71 (Figures 4 A and $4 B)$. When compared to the normal samples $(n=52)$, the expression of RelB and ICAM1 in tumor samples $(n=497)$ were both significantly higher $(p=9.0237 E-03$ and 9.9639E-04, respectively) (Figures 4C and 4D). The interaction network generated by the GeneMANIA web portal indicated that RelB interacted with ICAM1 mainly in a pattern of co-expression, or mediated by RELA, NFKB2, NFKB1, MST1R, REL, NFKB1A, CXCL-13, ICAM3 and ITGAM in a small part (Figure 4E).

\section{Establishment of ICAM1-overexpressing DU145 cell line}

Western blotting displayed that the protein level of RelB was markedly decreased after the transfection of shRNA-RelB (Figure 5A). Compared with the sictrl cells, ICAM1 protein was also significantly down-regulated in the siRelB cells (Figure 5A). We further verified that the concentration of sICAM1 and protein expression of ICAM1 in exosomes derived from the siRelB cells were both significantly lower than those from the sictrl cells (Figure 5D and 5E). To explore the effect of ICAM1 on DU145, we established ICAM1-overexpressing and control cell lines by plasmid transfection. As shown in Figures 6B and 6C, the expression of ICAM1 in clone 2 was significantly higher than that in other clones and control cells both at mRNA and protein levels, indicating that the ICAM1- 
overexpressing cell line (clone-2, named hICAM1) and control (named hctrl) were successfully established. hICAM1 had an increased concentration of sICAM1, as well as protein and mRNA levels of exosomal ICAM1. The siRelB cells had the lowest expression level of ICAM1 ( $p<0.05$; Figures 5D-5F).

\section{Carcinogenic characteristics of ICAM1 overexpressed DU145 cell line}

xCELLigence real-time cell analysis system showed that the cell index of the hICAM1 cell was slightly higher than that of the control cell, and the difference was statistically significant after culturing for $56 \mathrm{~h}$ or more (Figure $6 \mathrm{~A}$ ). CCK-8 assay indicated that the viability of hICAM1 was mildly superior to hctrl ( $p<$ 0.05; Figure 6B). ICAM1 overexpression had no significant influence on the apoptosis of DU145 (Figure 6C). The proportions of early apoptotic cells in hctrl group were $1.203 \pm 0.05(\%), 1.240 \pm 0.03(\%)$ and $0.687 \pm 0.04(\%)$ at $24 \mathrm{~h}, 48 \mathrm{~h}$ and $72 \mathrm{~h}$; while those in hICAM1 group were $1.037 \pm 0.04(\%), 1.240 \pm 0.03(\%)$ and $0.657 \pm 0.04(\%)$. We also found that the hICAM1 cells migrated and invaded markedly faster than the hctrl cells during the $24-h^{\prime}$ successive monitoring (Figures $6 \mathrm{D}-6 \mathrm{E})$.

To deeper understand the mechanism that ICAM1 overexpression strengthened the aggressiveness of DU145, the expression of metastasis-related proteins, such as integrin $\beta-1$, MMP9 (matrix metalloproteinase 9), and uPA (urokinase-type plasminogen activator) were determined by western blotting. Figure 7F displayed that the expression of integrin $\beta-1$ was increased in the hICAM1 cells. No significant differences were observed in the expression of MMP9 and uPA.

Thus, ICAM1 overexpression significantly reinforced the proliferation, migration, and invasion abilities of DU145 cells, indicating a more aggressive phenotype. The upregulated integrin $\beta-1$ participated in migration and invasion activities.

\section{Discussion}

It remains largely unclear how exosomes from tumor microenvironment regulate PC oncogenesis and progression. Previous studies suggest that RelB was positively correlated with the proliferation, migration, and invasion properties of the DU145 prostatic cell line. The silence of RelB leads to reduced cell growth, migration, and invasion abilities of DU145 cells. To this end, we have characterized the exosomal protein profile of RelB-knockdown cells. We discovered that 55 proteins were downregulated and 137 proteins were upregulated in the presence of RelB-knockdown, and the downregulated exosomal ICAM1 maybe a putative target of RelB in the regulation of PC proliferation and metastasis.

Secreted microvesicles were separated from DU145 conditioned media by ultracentrifugation. We verified those free vesicles as exosomes by electron microscopy, NanoSight analysis, and examination of the exosomal protein markers CD63, flotillin, and CD81. Based on the LC-MS technique and bioinformatics analysis, we characterized the proteins regulated by exosomes derived from the RelB knockdown DU145 cell line for the first time. 1,259 proteins were identified and $89.4 \%$ proteins can be retrieved in the Exocarta database. The canonical proteins in exosomes could be identified, such as heat shock proteins, cytoskeletal proteins, endosomal molecules, multivesicular tetraspanins, antigen presentation molecules, adhesion proteins, immunoglobulin family members, and so on [21]. Moreover, exosomal proteins specific for DU145 cells were detected, exemplified by integrin family members, CD276, ANXA2, CLSTN1, FASN, and FLNC [7]. These results demonstrated that exosomes from PC DU145 cells not only have similar features as exosomes from other cell types but also have specific characteristics.

According to the screening criteria, 192 DEPs were identified. Except for the 39 DEPs presenting in only one cell line, the FC of 153 DEPs varied from 1.286 to 47.986. The GO grouping system classified the proteins basing on their functional properties. Most of the DEPs originate from the cytoplasm, exosomes, and nucleus, manifesting the common biological processes, including signaling pathways, metabolism regulation, cell-cell interaction, cell-matrix interaction, and so on. Under the terms of biological process and molecular function of GO, as well as KEGG analysis, some DEPs were involved in cell-cell adhesion, cell adhesion molecule activity, and focal adhesion. Among the DEPs, ICAM1 attracted our attention. Further, we obtained important data showing the tight correlation between RelB and ICAM1 from the UALCAN website. Co-expression was the main pattern RelB interacting with ICAM1 based on the GeneMANIA tool. A kappa B-site had been identified in the promoter of the ICAM1 gene [22]. In summary, we speculated that ICAM1 was a target downstream of RelB.

ICAM1 was downregulated by 2.136 fold in exosomes derived from the siRelB cells. ICAM1 was annotated to origin from the plasma membrane and exosomes, was of transmembrane structure with an extracellular domain, belonging to the immunoglobulins adhesive molecules family. Exosomal ICAM1 was found to be regulated by the NF-KB signaling through KEGG enrichment. In the previous study, we have discovered that the mRNA expression of ICAM1 in the siRelB cells was lower than that in the sictrl cells by high throughput screening of differentially expressed mRNA (data not published). We had also verified the lower protein expression of ICAM1 or exosomal ICAM1 in RelB-knockdown DU145 cells. The TCGA dataset indicated that both of ICAM1 and RelB expressed higher in tumor samples when compared to normal samples. Thus, we proposed that ICAM1 was positively regulated by RelB.

ICAM1 is a multifunctional transmembrane glycoprotein, regulated by multipath such as PKC, MAP, and NF-KB signal pathways, and exerted positive or negative functions in cancer development. Compared to non-metastatic PC cell line P69, miR-296-3p was much higher in highly metastatic cell line M12, by targeting and inhibiting the expression of ICAM1 [23]. Biological studies showed that cells with higher expression of ICAM1 had enhanced abilities of cell proliferation, migration, and invasion. Importantly, ICAM1 existed both on plasma membranes and in exosomes, contributing together to the phenotypical heterogeneity. Yu et al found that the migration of prostate cancer cells was enhanced after bradykinin treatment by increasing ICAM1 expression, though signal transduction pathways induced by B2 receptor, AP-115, Akt, and PI3K [24]. Proteomic analysis of exosomes from nasopharyngeal carcinoma cells identified that the expression of ICAM1 was upregulated, which played a critical role in exosomes-induced angiogenesis. It has also been demonstrated that the internalization of exosomes could result in the alteration of ICAM1 expression in recipient HUVECs [25].

To further investigate the mechanism of strengthened migration and invasion upon ectopic expression of ICAM1 in DU145 cells, we detected the protein levels of integrin $\beta-1$, MMP9, and uPA. The protein level of integrin $\beta-1$ was up-regulated in ICAM1-overexpressing DU145 cells. In our previous study, we have verified that the RelB-knockdown suppressed the migration and invasion abilities of DU145 cells, likely due to the downregulated integrin $\beta-1$ [12]. Taken together, 
integrin $\beta-1$ was likely involved in regulating the migration and invasion properties of DU145 cells, which was affected by the RelB-ICAM1 axis. Integrin $\beta-1$, a member of heterodimeric transmembrane cell surface receptors, plays a key role in regulating cell metastatic growth. Activation of $\beta 1$ integrin and the autophosphorylation induced by integrin of focal adhesion kinase in PCa cells correlated with metastatic potential in vivo [26]. Trop-2, a transmembrane molecule, could enhance the migratory and metastatic abilities of PC cells by up-regulating integrin $\beta$-1-dependent cell adhesion to fibronectin and signaling [27]. MMP9, a major component of the basement membrane, is a pivotal enzyme for degrading type IV collagen. uPA can degrade the components of the ECM, including laminin, fibronectin, and collagen. MMP9 and uPA had been reported to contribute to the metastasis of PC [28, 29]. However, ICAM1 had no effect on the protein expressions of MMP9 and UPA in DU145 cells in our study.

\section{Conclusions}

Our study identified 192 exosomal DEPs due to lacking RelB in DU145 cells. The RelB-knockdown led to an abundant reduction of exosomal ICAM1. ICAM1 was demonstrated to enhance the proliferation, migration, and invasion abilities of DU145 cells. Exosomal ICAM1 might be an important factor in facilitating PC progression. Here, we also provided rich proteomics data containing numerous individual proteins that were worth in-depth studies. Clinical samples were in need to validate the correlation between ICAM1 expression and other clinical indexes in PC.

\section{Abbreviations}

PC: prostate cancer; LC-MS: liquid chromatography-mass spectrometry; GO: gene ontology; KEGG: Kyoto Encyclopedia of Genes and Genomes; DEPs: differentially expressed proteins; ICAM1: intercellular adhesion molecule-1; NF-KB: nuclear factor K-light-chain-enhancer of activated B cells; TME: tumor microenvironment; MS: mass spectrometry; ATCC: American Type Culture Collection; STR: short tandem repeat; FBS: fetal bovine serum; CD: clusters of differentiation; DTT: dithiothreitol; TEAB: triethylamine-carbonic acid buffer; IAA: iodoacetamide; AGC: automatic gain control; HCD: higher-energy collisional dissociation; FDR: false discovery rate; iBAQ: intensity-based absolute quantification; FC: fold change; LFQ: label-free quantification; TCGA: the cancer genome atlas; PPI: protein-protein interaction; sICAM1: soluble ICAM1; CCK-8: cell counting kit-8; OD: optical density; MMP9: matrix metallopeptidase 9; uPA: urokinase plasminogen activator; HSP90: chaperones heat shock protein 90खHSP70: chaperones heat shock protein 70.

\section{Declarations}

\section{Ethical approval}

All procedures performed in studies involving human participants were following the Ethics Committee of Nanjing Medical University Affiliated Suzhou Hospital.

\section{Funding statement}

This study was funded by Suzhou Natural Science Foundation (grant number SS201875), Special Technical Project of Diagnosis and Treatment of Key Clinical Diseases of Suzhou (grant number LCZX201813), Guiding Projects of Suzhou Science and Technology Plan (grant number SYSD2016112), and Technology and Education, Jiangsu Provincial Medical Youth Talent (grant number QNRC2016725).

\section{Acknowledgements}

Not applicable.

\section{Conflict of interest statement}

The authors have declared no financial/commercial conflicts of interest.

\section{Data availability statement}

The data used to support the findings of this study are included within the article, or available from the corresponding author upon request.

\section{Consent for publication}

All authors consent for publication.

\section{Authors' contributions}

FG and QS designed the research. WJL and JJX performed the research and analyzed the data. LC and LJZ supported for the bioanalysis of raw data. FG and WJL wrote the paper. All authors have read and approved the final version of this manuscript.

\section{Author details}

${ }^{1}$ Department of Oncology, The First Affiliated Hospital of Soochow University, Suzhou, Jiangsu 215006. ${ }^{2}$ Department of Clinical Laboratory, Nanjing Medical University Affiliated Suzhou Hospital, Suzhou, Jiangsu 215002. ${ }^{3}$ Department of Clinical Laboratory, The First Affiliated Hospital of Soochow University, Suzhou, Jiangsu 215006. ${ }^{4}$ Department of Oncology, Shanghai East Hospital, Tongji University School of Medicine, Shanghai, 200123. ${ }^{5}$ Suzhou Institute of Systems Medicine, Chinese Academy of Medical Sciences \& Peking Union Medical College, Suzhou, Jiangsu 215123. ${ }^{6}$ Department of Urology, Nanjing 
Medical University Affiliated Suzhou Hospital, Suzhou 215001, China. ${ }^{7}$ Department of Oncology, Nanjing Medical University Affiliated Suzhou Hospital, Suzhou 215001, China.

\section{References}

1. Siegel RL, Miller KD, Jemal A: Cancer statistics, 2020. CA Cancer J Clin 2020, 70(1):7-30.

2. Weidle HU, Birzele F, Kollmorgen G, RÜGer R: The Multiple Roles of Exosomes in Metastasis. Cancer Genomics \& Proteomics 2017, 14(1):1-16.

3. Wortzel I, Dror S, Kenific CM, Lyden D: Exosome-Mediated Metastasis: Communication from a Distance. Developmental cel/ 2019, 49(3):347-360.

4. Melo SA, Sugimoto H, O'Connell JT, Kato N, Villanueva A, Vidal A, Qiu L, Vitkin E, Perelman LT, Melo CA et al: Cancer exosomes perform cell-independent microRNA biogenesis and promote tumorigenesis. Cancer Cell 2014, 26(5):707-721.

5. Hosseini-Beheshti E, Choi W, Weiswald LB, Kharmate G, Ghaffari M, Roshan-Moniri M, Hassona MD, Chan L, Chin MY, Tai IT et al: Exosomes confer prosurvival signals to alter the phenotype of prostate cells in their surrounding environment. Oncotarget 2016, 7(12):14639-14658.

6. Shiao S, Chu G, Chung L: Regulation of prostate cancer progression by the tumor microenvironment. Cancer Lett 2016, 380(1):340-348.

7. Liu C, Hsieh C, Shen C, Lin C, Shigemura K, Sung S: Exosomes from the tumor microenvironment as reciprocal regulators that enhance prostate cancer progression. International journal of urology : official journal of the Japanese Urological Association 2016, 23(9):734-744.

8. Zhou X, Shan Z, Yang H, Xu J, Li W, Guo F: RelB plays an oncogenic role and conveys chemo-resistance to DLD-1 colon cancer cells. Cancer cell international 2018, 18:181.

9. Tao Y, Liu Z, Hou Y, Wang S, Liu S, Jiang Y, Tan D, Ge Q, Li C, Hu Y et al: Alternative NF-kappaB signaling promotes colorectal tumorigenesis through transcriptionally upregulating Bcl-3. Oncogene 2018, 37(44):5887-5900.

10. Xu J, Zhou P, Wang W, Sun A, Guo F: RelB, together with RelA, sustains cell survival and confers proteasome inhibitor sensitivity of chronic lymphocytic leukemia cells from bone marrow. J Mol Med (Berl) 2014, 92(1):77-92.

11. Xu Y, Josson S, Fang F, Oberley T, St Clair D, Wan X, Sun Y, Bakthavatchalu V, Muthuswamy A, St Clair W: RelB enhances prostate cancer growth: implications for the role of the nuclear factor-kappaB altemative pathway in tumorigenicity. Cancer Res 2009, 69(8):3267-3271.

12. Wang J, Yi S, Zhou J, Zhang Y, Guo F: The NF-kappaB subunit RelB regulates the migration and invasion abilities and the radio-sensitivity of prostate cancer cells. International journal of oncology 2016, 49(1):381-392.

13. Zhu HC, Qiu T, Dan C, Liu XH, Hu CH: Blockage of RelB expression by gene silencing enhances the radiosensitivity of androgenindependent prostate cancer cells. Mol Med Rep 2015, 11(2):1167-1173.

14. Zhang Y, Xu Z, Ding J, Tan C, Hu W, Li Y, Huang W, Xu Y: HZO8 suppresses RelB-activated MnSOD expression and enhances Radiosensitivity of prostate Cancer cells. J Exp Clin Cancer Res 2018, 37(1):174.

15. Chen C, Luo F, Liu X, Lu L, Xu H, Yang Q, Xue J, Shi L, Li J, Zhang A et al: NF-kB-regulated exosomal miR-155 promotes the inflammation associated with arsenite carcinogenesis. Cancer Lett 2017, 388:21-33.

16. Ying W, Riopel M, Bandyopadhyay G, Dong Y, Birmingham A, Seo JB, Ofrecio JM, Wollam J, Hernandez-Carretero A, Fu W et al: Adipose Tissue Macrophage-Derived Exosomal miRNAs Can Modulate In Vivo and In Vitro Insulin Sensitivity. Cell 2017, 171(2):372-384 e312.

17. Zou Y, Gong P, Zhao W, Zhang J, Wu X, Xin C, Xiong Z, Li Z, Wu X, Wan Q et al: Quantitative iTRAQ-based proteomic analysis of piperine protected cerebral ischemia/reperfusion injury in rat brain. Neurochemistry international 2019, 124:51-61.

18. She X, Zhang P, Gao Y, Zhang L, Wang Q, Chen H, Calderone R, Liu W, Li D: A mitochondrial proteomics view of complex I deficiency in Candida albicans Mitochondrion 2018, 38:48-57.

19. Chandrashekar DS, Bashel B, Balasubramanya SAH, Creighton CJ, Ponce-Rodriguez I, Chakravarthi B, Varambally S: UALCAN: A Portal for Facilitating Tumor Subgroup Gene Expression and Survival Analyses. Neoplasia 2017, 19(8):649-658.

20. Warde-Farley D, Donaldson SL, Comes O, Zuberi K, Badrawi R, Chao P, Franz M, Grouios C, Kazi F, Lopes CT et al: The GeneMANIA prediction server: biological network integration for gene prioritization and predicting gene function. Nucleic Acids Research 2010, 38(Web Server issue):W214-220.

21. Thery C, Zitvogel L, Amigorena S: Exosomes: composition, biogenesis and function. Nature reviews Immunology 2002, 2(8):569-579.

22. Wissink S, van de Stolpe A, Caldenhoven E, Koenderman L, van der Saag PT: NF-kappa B/Rel family members regulating the ICAM-1 promoter in monocytic THP-1 cells. Immunobiology 1997, 198(1-3):50-64.

23. Liu X, Chen Q, Yan J, Wang Y, Zhu C, Chen C, Zhao X, Xu M, Sun Q, Deng R et al: MiRNA-296-3p-ICAM-1 axis promotes metastasis of prostate cancer by possible enhancing survival of natural killer cell-resistant circulating tumour cells. Cell Death Dis 2013, 4:e928.

24. Yu HS, Lin TH, Tang CH: Involvement of intercellular adhesion molecule-1 up-regulation in bradykinin promotes cell motility in human prostate cancers. International Journal of Molecular Sciences 2013, 14(7):13329-13345.

25. Chan Y, Zhang H, Liu P, Tsao S, Lung M, Mak N, Ngok-Shun Wong R, Ying-Kit Yue P: Proteomic analysis of exosomes from nasopharyngeal carcinoma cell identifies intercellular transfer of angiogenic proteins. International journal of cancer 2015, 137(8):1830-1841.

26. Lee YC, Jin JK, Cheng CJ, Huang CF, Song JH, Huang M, Brown WS, Zhang S, Yu-Lee LY, Yeh ET et al: Targeting constitutively activated beta1 integrins inhibits prostate cancer metastasis. Molecular cancer research : MCR 2013, 11(4):405-417.

27. Trerotola M, Jernigan DL, Liu Q, Siddiqui J, Fatatis A, Languino LR: Trop-2 promotes prostate cancer metastasis by modulating beta(1) integrin functions Cancer Res 2013, 73(10):3155-3167.

28. Zeng Y, Yang Y: Piperine depresses the migration progression via downregulating the Akt/mTOR/MMP9 signaling pathway in DU145 cells. Mol Med Rep 2018, 17(5):6363-6370.

Page $8 / 18$ 
29. Shi C, Zhang N, Feng Y, Cao J, Chen X, Liu B: Aspirin Inhibits IKK-beta-mediated Prostate Cancer Cell Invasion by Targeting Matrix Metalloproteinase-9 and Urokinase-Type Plasminogen Activator. Cellular physiology and biochemistry : international journal of experimental cellular physiology, biochemistry, and pharmacology 2017, 41(4):1313-1324.

\section{Tables}




\begin{tabular}{|c|c|c|c|c|c|c|c|c|c|}
\hline \multirow[t]{2}{*}{ ID } & \multirow{2}{*}{$\begin{array}{l}\text { Gene } \\
\text { Name }\end{array}$} & \multirow[t]{2}{*}{ Full Name } & \multirow[t]{2}{*}{ siRelB } & \multirow[t]{2}{*}{ sictrl } & \multicolumn{3}{|l|}{ GO analysis } & \multirow{2}{*}{$\begin{array}{l}\text { Expression } \\
\text { in Prostate } \\
\text { cancer }\end{array}$} & \multirow{2}{*}{$\begin{array}{l}\text { COSMI } \\
\text { (prosta }\end{array}$} \\
\hline & & & & & $\begin{array}{l}\text { Cellular } \\
\text { component }\end{array}$ & $\begin{array}{l}\text { Molecular } \\
\text { function }\end{array}$ & Biological process & & \\
\hline 015460 & P4HA2 & $\begin{array}{l}\text { Prolyl 4-hydroxylase } \\
\text { subunit alpha-2 }\end{array}$ & + & & $\begin{array}{l}\text { Endoplasmic } \\
\text { reticulum }\end{array}$ & Catalytic activity; & $\begin{array}{l}\text { Metabolism;Energy } \\
\text { pathways;Peptide } \\
\text { metabolism; }\end{array}$ & No & Yes \\
\hline 060271 & SPAG9 & $\begin{array}{l}\text { C-Jun-amino-terminal } \\
\text { kinase-interacting } \\
\text { protein } 4\end{array}$ & + & & $\begin{array}{l}\text { Plasma } \\
\text { membrane; } \\
\text { Integral to } \\
\text { membrane; } \\
\text { Nucleus; } \\
\text { Cytoplasm; } \\
\text { Exosomes; } \\
\text { Lysosome }\end{array}$ & unknown & $\begin{array}{l}\text { Cell growth and/or } \\
\text { maintenance }\end{array}$ & No & Yes \\
\hline 075674 & TOM1L1 & TOM1-like protein 1 & + & & $\begin{array}{l}\text { Golgi apparatus; } \\
\text { Cytosol; } \\
\text { Cytoplasm; } \\
\text { Lysosome; } \\
\text { Endosome }\end{array}$ & $\begin{array}{l}\text { Receptor } \\
\text { signaling } \\
\text { complex scaffold } \\
\text { activity }\end{array}$ & $\begin{array}{l}\text { Cell } \\
\text { communication; } \\
\text { Signal } \\
\text { transduction }\end{array}$ & Yes & Yes \\
\hline 076071 & CIA01 & $\begin{array}{l}\text { Probable cytosolic } \\
\text { iron-sulfur protein } \\
\text { assembly protein } \\
\text { CIAO1 }\end{array}$ & + & & $\begin{array}{l}\text { Nucleus; } \\
\text { Cytoplasm; } \\
\text { MMXD complex }\end{array}$ & $\begin{array}{l}\text { Transcription } \\
\text { regulator activity }\end{array}$ & $\begin{array}{l}\text { Regulation of } \\
\text { nucleobase, } \\
\text { nucleoside, } \\
\text { nucleotide and } \\
\text { nucleic acid } \\
\text { metabolism }\end{array}$ & Yes & No \\
\hline P02788 & LTF & Lactotransferrin & + & & $\begin{array}{l}\text { Plasma } \\
\text { membrane; Golgi } \\
\text { aparatus; } \\
\text { Nucleus; } \\
\text { Nucleolus; } \\
\text { Cytoplasm; } \\
\text { Exosomes; } \\
\text { Lysosome; } \\
\text { Endoplasmic } \\
\text { reticulum; } \\
\text { Secretory granule; } \\
\text { Extracellular; } \\
\text { Stored secretory; } \\
\text { others granule; }\end{array}$ & $\begin{array}{l}\text { Transporter } \\
\text { activity }\end{array}$ & Transport & Yes & Yes \\
\hline P10768 & ESD & $\begin{array}{l}\text { S-formylglutathione } \\
\text { hydrolase }\end{array}$ & + & & $\begin{array}{l}\text { Cytoplasm; } \\
\text { Exosomes; } \\
\text { Lysosome; } \\
\text { Cytoplasmic } \\
\text { membrane-- } \\
\text { bounded vesicle }\end{array}$ & Hydrolase activity & $\begin{array}{l}\text { Metabolism; } \\
\text { Energy pathways; }\end{array}$ & No & No \\
\hline P15924 & DSP & Desmoplakin & + & & $\begin{array}{l}\text { Plasma } \\
\text { membrane; } \\
\text { Nucleus; } \\
\text { Nucleolus; } \\
\text { Cytoplasm; } \\
\text { Exosomes; } \\
\text { Lysosome; } \\
\text { Extracellular; } \\
\text { Cytoskeleton; } \\
\text { Cornified } \\
\text { envelope }\end{array}$ & $\begin{array}{l}\text { Structural } \\
\text { constituent of } \\
\text { cytoskeleton }\end{array}$ & $\begin{array}{l}\text { Cell growth and/or } \\
\text { maintenance }\end{array}$ & No & Yes \\
\hline P17936 & IGFBP3 & $\begin{array}{l}\text { Insulin-like growth } \\
\text { factor-binding protein } \\
3\end{array}$ & + & & $\begin{array}{l}\text { Plasma } \\
\text { membrane; } \\
\text { Nucleus; } \\
\text { Cytoplasm; } \\
\text { Extracellular; } \\
\text { Extracellular } \\
\text { region; } \\
\text { Extracellular } \\
\text { space; }\end{array}$ & $\begin{array}{l}\text { Growth factor } \\
\text { binding }\end{array}$ & $\begin{array}{l}\text { Cell } \\
\text { communication; } \\
\text { Signal } \\
\text { transduction; } \\
\text { Apoptosis }\end{array}$ & Yes & Yes \\
\hline P27694 & RPA1 & $\begin{array}{l}\text { Replication protein A } \\
70 \mathrm{kDa} \text { DNA-binding } \\
\text { subunit }\end{array}$ & + & & $\begin{array}{l}\text { Nucleus; Actin } \\
\text { cytoskeleton; } \\
\text { Cytoplasm; PML } \\
\text { body; } \\
\text { Nucleoplasm; } \\
\text { Centrosome; DNA } \\
\text { replication factor } \\
\text { A complex; }\end{array}$ & DNA binding & $\begin{array}{l}\text { Regulation of } \\
\text { nucleobase, } \\
\text { nucleoside, } \\
\text { nucleotide and } \\
\text { nucleic acid } \\
\text { metabolism }\end{array}$ & Yes & Yes \\
\hline
\end{tabular}




\begin{tabular}{|c|c|c|c|c|c|c|c|c|}
\hline P28070 & PSMB4 & $\begin{array}{l}\text { Proteasome subunit } \\
\text { beta type- } 4\end{array}$ & + & $\begin{array}{l}\text { Nucleus; } \\
\text { Cytoplasm; } \\
\text { Exosomes; } \\
\text { Lysosome; } \\
\text { Centrosome; } \\
\text { Proteasome } \\
\text { complex; } \\
\text { Intermediate } \\
\text { filament } \\
\text { cytoskeleton; }\end{array}$ & $\begin{array}{l}\text { Ubiquitin-specific } \\
\text { protease activity }\end{array}$ & $\begin{array}{l}\text { Protein } \\
\text { metabolism }\end{array}$ & Yes & No \\
\hline P28074 & PSMB5 & $\begin{array}{l}\text { Proteasome subunit } \\
\text { beta type- } 5\end{array}$ & + & $\begin{array}{l}\text { Nucleus; Cytosol; } \\
\text { Cytoplasm; } \\
\text { Exosomes; } \\
\text { Proteasome } \\
\text { complex; }\end{array}$ & $\begin{array}{l}\text { Ubiquitin-specific } \\
\text { protease activity }\end{array}$ & $\begin{array}{l}\text { Protein } \\
\text { metabolism }\end{array}$ & No & No \\
\hline P34096 & RNASE4 & Ribonuclease 4 & + & $\begin{array}{l}\text { Secretory granule; } \\
\text { Extracellular; } \\
\text { others }\end{array}$ & $\begin{array}{l}\text { Ribonuclease } \\
\text { activity }\end{array}$ & $\begin{array}{l}\text { Regulation of } \\
\text { nucleobase, } \\
\text { nucleoside, } \\
\text { nucleotide and } \\
\text { nucleic acid } \\
\text { metabolism }\end{array}$ & No & No \\
\hline P50579 & METAP2 & $\begin{array}{l}\text { Methionine } \\
\text { aminopeptidase } 2\end{array}$ & + & $\begin{array}{l}\text { Cytoplasm; } \\
\text { Exosomes; } \\
\text { Lysosome; } \\
\text { Cytoplasmic } \\
\text { membrane- } \\
\text { bounded vesicle }\end{array}$ & $\begin{array}{l}\text { Translation } \\
\text { regulator activity }\end{array}$ & $\begin{array}{l}\text { Protein } \\
\text { metabolism }\end{array}$ & Yes & Yes \\
\hline P53999 & SUB1 & $\begin{array}{l}\text { Activated RNA } \\
\text { polymerase II } \\
\text { transcriptional } \\
\text { coactivator p15 }\end{array}$ & + & $\begin{array}{l}\text { Nucleus; } \\
\text { Nucleolus; } \\
\text { Mitochondrion; } \\
\text { Cytoplasm; } \\
\text { Exosomes; } \\
\text { Centrosome; } \\
\text { Transcription } \\
\text { factor complex; }\end{array}$ & $\begin{array}{l}\text { Transcription } \\
\text { factor activity }\end{array}$ & $\begin{array}{l}\text { Protein } \\
\text { metabolism }\end{array}$ & Yes & Yes \\
\hline P62834 & RAP1A & $\begin{array}{l}\text { Ras-related protein } \\
\text { Rap-1A }\end{array}$ & + & $\begin{array}{l}\text { Plasma } \\
\text { membrane; } \\
\text { Nucleus; } \\
\text { Mitochondrion; } \\
\text { Cytosol; } \\
\text { Cytoplasm; } \\
\text { Exosomes; } \\
\text { Perinuclear } \\
\text { region; Lysosome; } \\
\text { Late endosome; }\end{array}$ & GTPase activity & $\begin{array}{l}\text { Cell } \\
\text { communication; } \\
\text { Signal } \\
\text { transduction }\end{array}$ & Yes & No \\
\hline Q06124 & PTPN11 & $\begin{array}{l}\text { Tyrosine-protein } \\
\text { phosphatase non- } \\
\text { receptor type } 11\end{array}$ & + & $\begin{array}{l}\text { Plasma } \\
\text { membrane; } \\
\text { Cytosol; } \\
\text { Cytoplasm; }\end{array}$ & $\begin{array}{l}\text { Protein tyrosine } \\
\text { phosphatase } \\
\text { activity }\end{array}$ & $\begin{array}{l}\text { Cell } \\
\text { communication; } \\
\text { Signal } \\
\text { transduction }\end{array}$ & Yes & No \\
\hline Q08J23 & NSUN2 & $\begin{array}{l}\text { tRNA (cytosine(34)- } \\
\text { C(5))- } \\
\text { methyltransferase }\end{array}$ & + & $\begin{array}{l}\text { Nucleus; } \\
\text { Nucleolus; } \\
\text { Cytoplasm; }\end{array}$ & $\begin{array}{l}\text { RNA } \\
\text { methyltransferase } \\
\text { activity }\end{array}$ & unknown & No & No \\
\hline Q13564 & NAE1 & $\begin{array}{l}\text { NEDD8-activating } \\
\text { enzyme E1 regulatory } \\
\text { subunit }\end{array}$ & + & $\begin{array}{l}\text { Cytoplasm; } \\
\text { Lysosome; } \\
\text { Insoluble fraction }\end{array}$ & $\begin{array}{l}\text { Receptor } \\
\text { signaling } \\
\text { complex scaffold } \\
\text { activity }\end{array}$ & $\begin{array}{l}\text { Cell } \\
\text { communication; } \\
\text { Signal } \\
\text { transduction }\end{array}$ & No & No \\
\hline Q14160 & SCRIB & $\begin{array}{l}\text { Protein scribble } \\
\text { homolog }\end{array}$ & + & $\begin{array}{l}\text { Plasma } \\
\text { membrane; } \\
\text { Cytoplasm; } \\
\text { Exosomes; Cell- } \\
\text { cell junction; Cell } \\
\text { junction; Cell-cell } \\
\text { adherens } \\
\text { junction; Synapse; } \\
\text { Cell leading edge; } \\
\text { Postsynaptic } \\
\text { membrane; } \\
\text { Presynaptic } \\
\text { membrane; } \\
\text { Basolateral } \\
\text { membrane; Scrib- } \\
\text { APC-beta-catenin } \\
\text { complex; }\end{array}$ & $\begin{array}{l}\text { Ubiquitin-specific } \\
\text { protease activity }\end{array}$ & $\begin{array}{l}\text { Protein } \\
\text { metabolism }\end{array}$ & No & Yes \\
\hline Q15257 & PTPA & $\begin{array}{l}\text { Serine/threonine- } \\
\text { protein phosphatase } \\
\text { 2A activator }\end{array}$ & + & unknown & unknown & unknown & No & No \\
\hline Q5T749 & KPRP & $\begin{array}{l}\text { Keratinocyte proline- } \\
\text { rich protein }\end{array}$ & + & $\begin{array}{l}\text { Exosomes; } \\
\text { Cytoskeleton; }\end{array}$ & unknown & Cell differentiation & No & Yes \\
\hline
\end{tabular}




\begin{tabular}{|c|c|c|c|c|c|c|c|c|c|}
\hline Q8NBJ5 & COLGALT1 & $\begin{array}{l}\text { Procollagen } \\
\text { galactosyltransferase } \\
1\end{array}$ & + & & Exosomes; & unknown & unknown & No & Yes \\
\hline Q8IUR6 & CREBRF & $\begin{array}{l}\text { CREB3 regulatory } \\
\text { factor }\end{array}$ & + & & Nucleus; & DNA binding & $\begin{array}{l}\text { Regulation of } \\
\text { nucleobase, } \\
\text { nucleoside, } \\
\text { nucleotide and } \\
\text { nucleic acid } \\
\text { metabolism }\end{array}$ & No & Yes \\
\hline Q8NFZ4 & NLGN2 & Neuroligin-2 & + & & $\begin{array}{l}\text { Plasma } \\
\text { membrane; } \\
\text { Membrane; } \\
\text { Postsynaptic } \\
\text { membrane; }\end{array}$ & Binding & $\begin{array}{l}\text { Cell } \\
\text { communication; } \\
\text { Signal } \\
\text { transduction }\end{array}$ & No & No \\
\hline Q99574 & SERPINI1 & Neuroserpin & + & & $\begin{array}{l}\text { Cytoplasmic } \\
\text { vesicle }\end{array}$ & $\begin{array}{l}\text { Protease inhibitor } \\
\text { activity }\end{array}$ & $\begin{array}{l}\text { Protein } \\
\text { metabolism }\end{array}$ & Yes & Yes \\
\hline Q9HB63 & NTN4 & Netrin-4 & + & & Extracellular; & $\begin{array}{l}\text { Extracellular } \\
\text { matrix structural } \\
\text { constituent }\end{array}$ & unknown & No & Yes \\
\hline 015118 & NPC1 & $\begin{array}{l}\text { Niemann-Pick C1 } \\
\text { protein }\end{array}$ & & + & $\begin{array}{l}\text { Plasma } \\
\text { membrane; } \\
\text { Integral to } \\
\text { membrane; } \\
\text { Integral to plasma } \\
\text { membrane; } \\
\text { Perinuclear region } \\
\text { of cytoplasm; } \\
\text { Cytoplasm; } \\
\text { Exosomes; } \\
\text { Lysosome; } \\
\text { Endoplasmic } \\
\text { reticulum; } \\
\text { Membrane; } \\
\text { Nuclear envelope; }\end{array}$ & Receptor activity & $\begin{array}{l}\text { Cell growth and/or } \\
\text { maintenance }\end{array}$ & Yes & Yes \\
\hline P23588 & EIF4B & $\begin{array}{l}\text { Eukaryotic } \\
\text { translation initiation } \\
\text { factor 4B }\end{array}$ & & + & $\begin{array}{l}\text { Cytosol; } \\
\text { Ribosome; } \\
\text { Cytoplasm; } \\
\text { Eukaryotic } \\
\text { translation } \\
\text { initiation factor } \\
\text { 4F complex }\end{array}$ & $\begin{array}{l}\text { Translation } \\
\text { regulator activity }\end{array}$ & $\begin{array}{l}\text { Protein } \\
\text { metabolism }\end{array}$ & Yes & No \\
\hline P52888 & THOP1 & $\begin{array}{l}\text { Thimet } \\
\text { oligopeptidase }\end{array}$ & & + & $\begin{array}{l}\text { Plasma } \\
\text { membrane; } \\
\text { Cytoplasm; } \\
\text { Extracellular; }\end{array}$ & $\begin{array}{l}\text { Metallopeptidase } \\
\text { activity }\end{array}$ & $\begin{array}{l}\text { Protein } \\
\text { metabolism }\end{array}$ & Yes & No \\
\hline P61221 & ABCE1 & $\begin{array}{l}\text { ATP-binding cassette } \\
\text { sub- } \\
\text { family E member } 1\end{array}$ & & + & $\begin{array}{l}\text { Mitochondrion; } \\
\text { Cytoplasm; } \\
\text { Centrosome; }\end{array}$ & $\begin{array}{l}\text { Transporter } \\
\text { activity }\end{array}$ & Transport & Yes & Yes \\
\hline P62081 & RPS7 & $\begin{array}{l}40 S \text { ribosomal } \\
\text { protein S7 }\end{array}$ & & + & $\begin{array}{l}\text { Ribonucleoprotein } \\
\text { complex; } \\
\text { Nucleolus; } \\
\text { Cytosolic small } \\
\text { ribosomal } \\
\text { subunit; Cytosol; } \\
\text { Ribosome; } \\
\text { Exosomes; } \\
\text { Lysosome; } \\
\text { Centrosome; }\end{array}$ & $\begin{array}{l}\text { Structural } \\
\text { constituent of } \\
\text { ribosome }\end{array}$ & $\begin{array}{l}\text { Protein } \\
\text { metabolism }\end{array}$ & No & Yes \\
\hline P98095 & FBLN2 & Fibulin-2 & & + & $\begin{array}{l}\text { Extracellular; } \\
\text { Proteinaceous } \\
\text { extracellular } \\
\text { matrix; }\end{array}$ & $\begin{array}{l}\text { Extracellular } \\
\text { matrix structural } \\
\text { constituent }\end{array}$ & $\begin{array}{l}\text { Cell growth and/or } \\
\text { maintenance }\end{array}$ & No & Yes \\
\hline Q6UVK1 & CSPG4 & $\begin{array}{l}\text { Chondroitin sulfate } \\
\text { proteoglycan } 4\end{array}$ & & + & $\begin{array}{l}\text { Plasma } \\
\text { membrane; } \\
\text { Integral to plasma } \\
\text { membrane; } \\
\text { Exosomes; Cell } \\
\text { surface; } \\
\text { Membrane; }\end{array}$ & Protein binding & $\begin{array}{l}\text { Cell } \\
\text { communication; } \\
\text { Signal } \\
\text { transduction }\end{array}$ & Yes & Yes \\
\hline Q9BR76 & COR01B & Coronin-1B & & + & $\begin{array}{l}\text { Nucleus; } \\
\text { Cytoplasm; } \\
\text { Exosomes; } \\
\text { Cytoskeleton; }\end{array}$ & unknown & $\begin{array}{l}\text { Signal } \\
\text { transduction }\end{array}$ & Yes & No \\
\hline Q9NY26 & SLC39A1 & Zinc transporter ZIP1 & & + & $\begin{array}{l}\text { Plasma } \\
\text { membrane; } \\
\text { Integral to }\end{array}$ & $\begin{array}{l}\text { Auxiliary } \\
\text { transport protein } \\
\text { activity }\end{array}$ & Transport & Yes & Yes \\
\hline
\end{tabular}

Page 12/18 


\begin{tabular}{|c|c|c|c|c|c|c|c|c|}
\hline & & & & $\begin{array}{l}\text { membrane; Golgi } \\
\text { aparatus; } \\
\text { Membrane } \\
\text { fraction; } \\
\text { Lysosome; } \\
\text { Endoplasmic } \\
\text { reticulum; }\end{array}$ & & & & \\
\hline Q9UNS2 & COPS3 & $\begin{array}{l}\text { COP9 signalosome } \\
\text { complex subunit } 3\end{array}$ & + & $\begin{array}{l}\text { Cytoplasm; } \\
\text { Lysosome; } \\
\text { Insoluble fraction }\end{array}$ & $\begin{array}{l}\text { Transcription } \\
\text { regulator activity }\end{array}$ & $\begin{array}{l}\text { Cell } \\
\text { communication; } \\
\text { Signal } \\
\text { transduction }\end{array}$ & Yes & Yes \\
\hline P01857 & IGHG1 & $\begin{array}{l}\text { Immunoglobulin } \\
\text { heavy constant } \\
\text { gamma } 1\end{array}$ & + & unknown & unknown & unknown & No & No \\
\hline P04818 & TYMS & $\begin{array}{l}\text { Thymidylate } \\
\text { synthase }\end{array}$ & + & $\begin{array}{l}\text { Nucleus; } \\
\text { Nucleolus; } \\
\text { Mitochondrion; } \\
\text { Cytoplasm; }\end{array}$ & Ligase activity & $\begin{array}{l}\text { Metabolism; } \\
\text { Energy pathways }\end{array}$ & Yes & No \\
\hline P51693 & APLP1 & Amyloid-like protein 1 & + & $\begin{array}{l}\text { Plasma } \\
\text { membrane; Golgi } \\
\text { aparatus; } \\
\text { Perinuclear region } \\
\text { of cytoplasm; } \\
\text { Cytoplasm; } \\
\text { Perinuclear } \\
\text { region; } \\
\text { Endoplasmic } \\
\text { reticulum; } \\
\text { Extracellular; } \\
\text { Basement } \\
\text { membrane; }\end{array}$ & $\begin{array}{l}\text { Transcription } \\
\text { regulator activity }\end{array}$ & $\begin{array}{l}\text { Cell } \\
\text { communication; } \\
\text { Signal } \\
\text { transduction; } \\
\text { Synapse } \\
\text { organization and } \\
\text { biogenesis }\end{array}$ & Yes & Yes \\
\hline
\end{tabular}

\section{Figures}

A

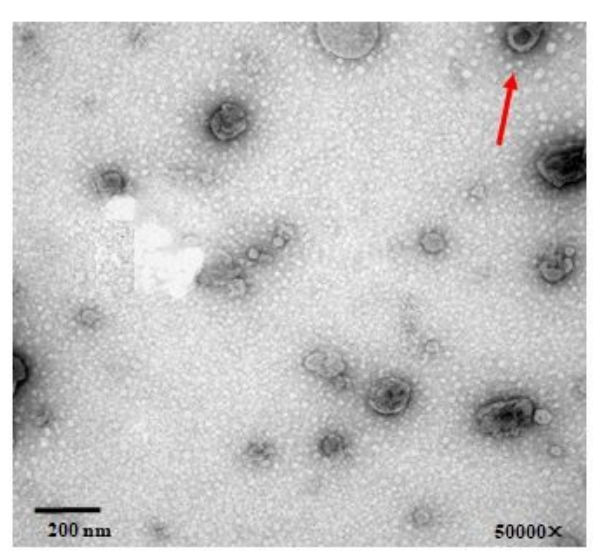

C

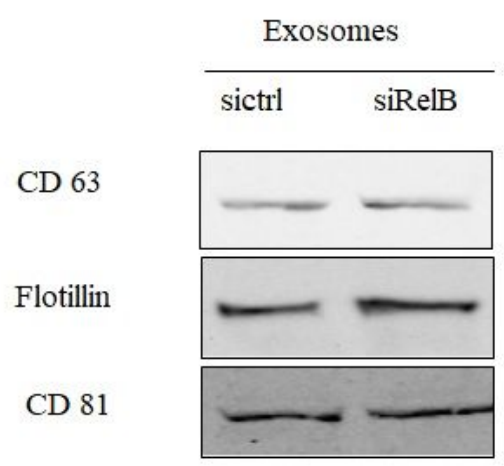

B

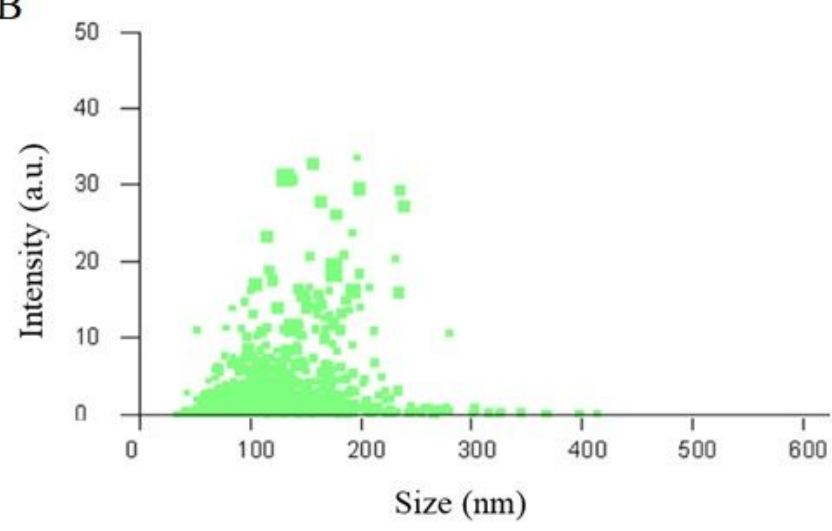

D

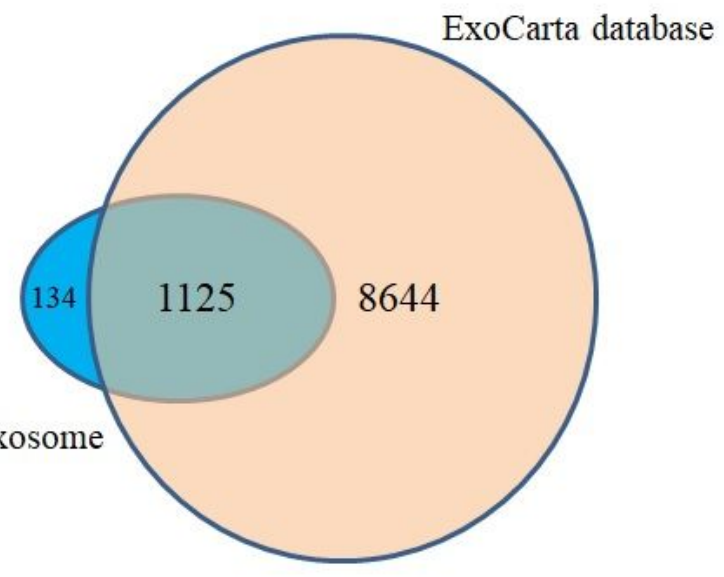




\section{Figure 1}

Quality control of exosome samples.(A) Electron microscopy analysis of exosomes secreted by DU145 cells. Scale bar, $200 \mathrm{~nm}$. The exosome was indicatedby thered arrow. (B) The particle size of the vesicles secreted was measured by NanoSight analysis. (C)Exosome protein markers CD63, flotillin, and CD81 were measured by western blot analysis. (D) Record of theexosomal proteins secreted by DU145 in the ExoCarta database.

A

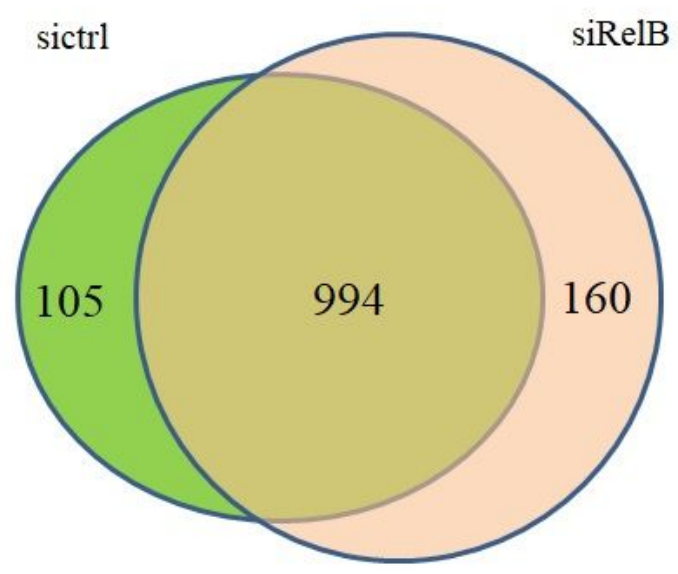

B PKM $=\frac{0.61}{0.98}$

HSPAS 0.780 .82

CFL1 $=0.670 .97$

$\mathrm{GPC1}=0.97$

HSP90B1 $1.00^{0.72}$

PRKCSH 1.18

O $\mathrm{CLU}=0.922^{0.89}$

$\stackrel{\circ}{\circ}$ APLP2 $\quad 0_{0.84}^{1.01}$

D. PLAU $=0.681 .23$

䒿 TUBB $\frac{0.94}{0} 1.14$

4 PSAP 1.11

VCP $\quad 1.322^{1.27}$

NPM1 $\quad 1.51 .31$

KRT2 -1.51

SDCBP $\quad 2.22$ 1.67

$\begin{array}{lll}\text { 苛 } & \text { SDCBP } & 1.88 \\ \text { f } & \text { AGRN } & -2.68\end{array}$

CALR 2.28 A. 1.78

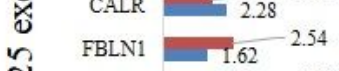

$\begin{array}{ll}\text { N HSP90AB1 } & 2.14 \\ 2.22\end{array}$

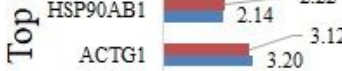

THBS1 $\quad 2.77-4.26$

$\begin{array}{ll}\text { UBA52 } & 3.92 \\ 4.37 & \end{array}$

HSP9OAAl -4.84

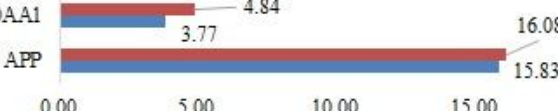

$\begin{array}{lllll}0.00 & 5.00 & 10.00 & 15.00 & 20.00\end{array}$

Relative amount (\%)
- sictrl

- siRelB

\section{Figure 2}

Totalproteome expression analysis. (A) Venn diagram of proteins in siRelB versus sictrlexosomes. (B) The percentages of the top 25 exosomal proteins in sictrl and siRelB cells, respectively. 
A
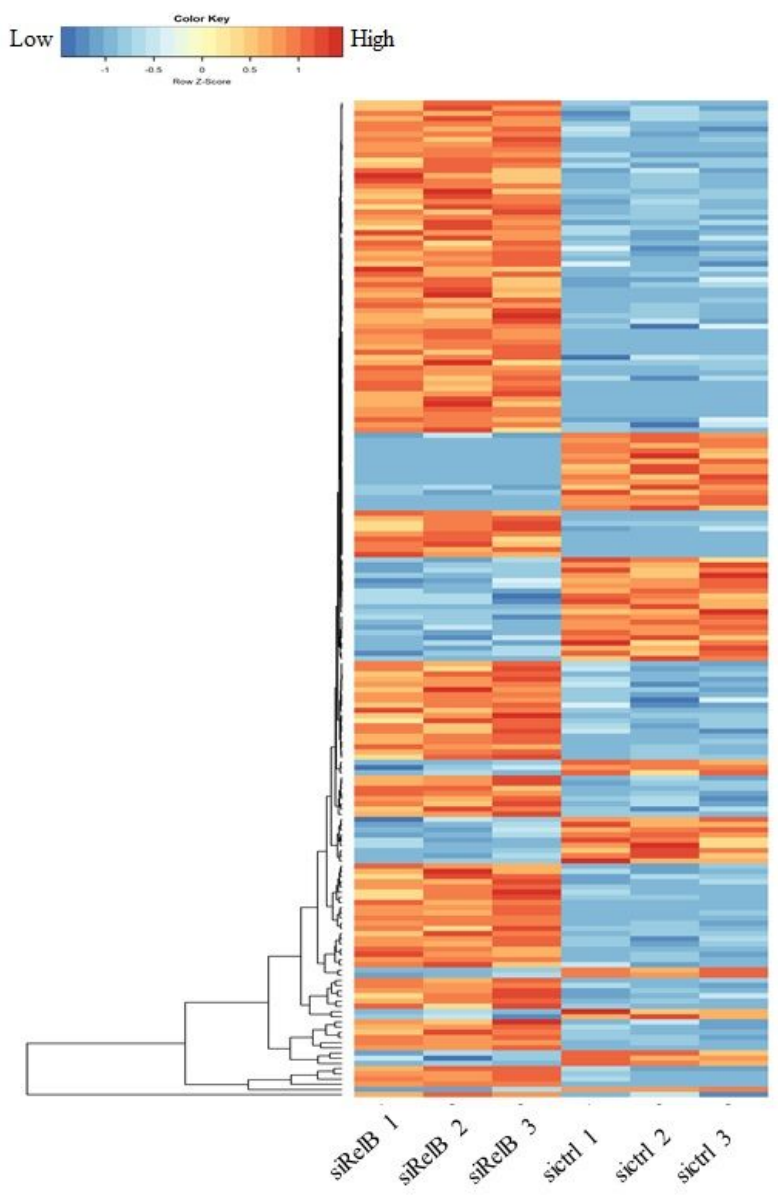

B

C

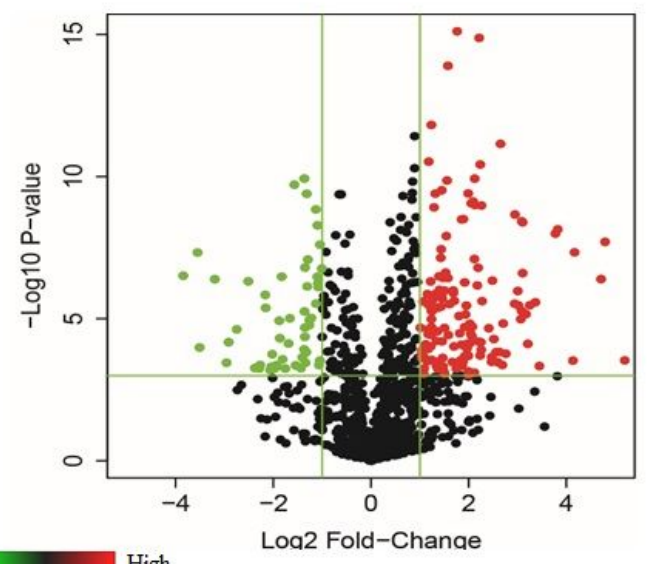

Low

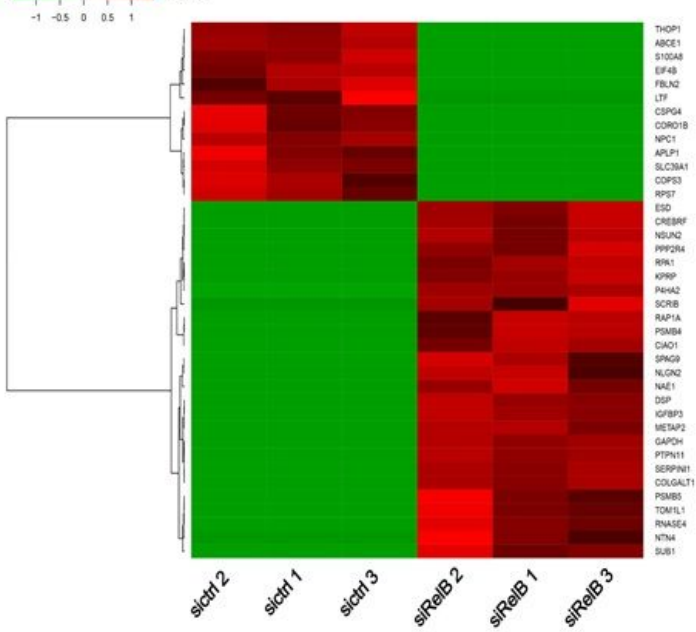

\section{Figure 3}

DEPs expression analysis.(A) 192 DEPs expression analysis by hierarchical clustering. (B) 153 DEPs expression analysis by volcano plot. Red and green dots indicated up-regulated and down-regulated proteins, respectively. (C) Heat map analysis of 39 DEPs expressed only in one type of cell. 

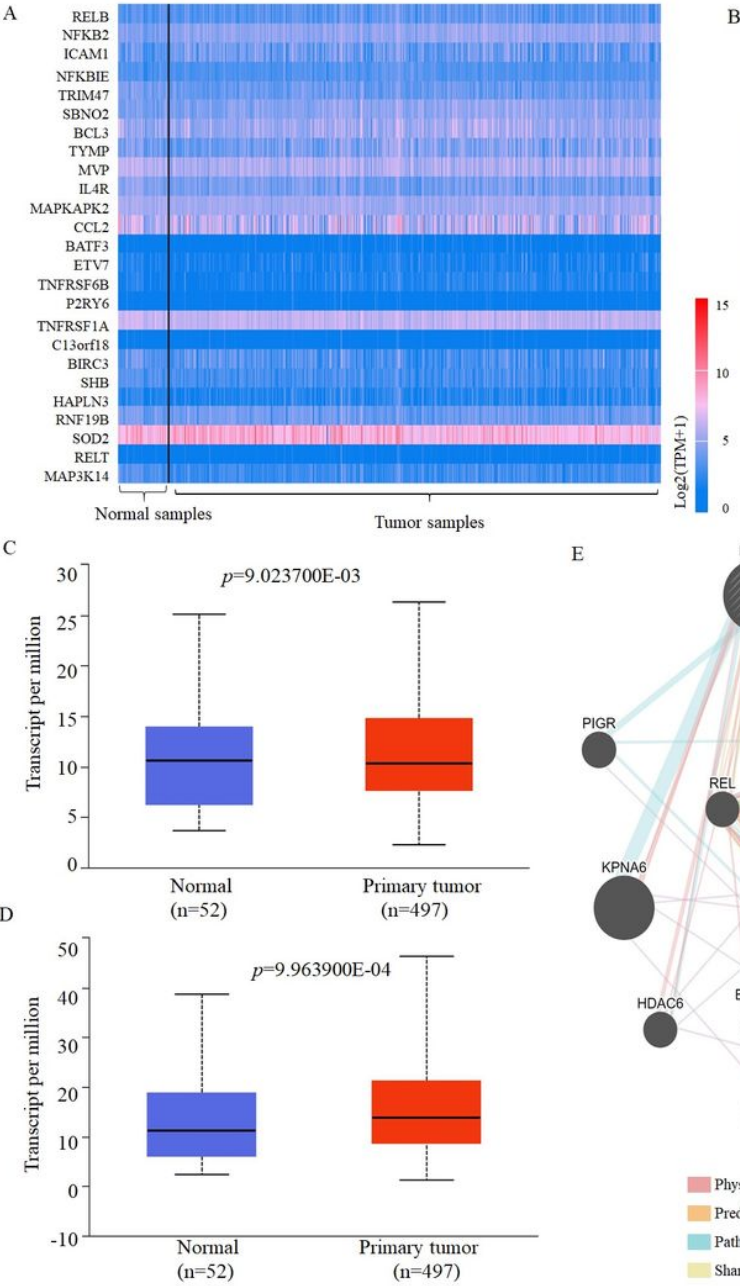

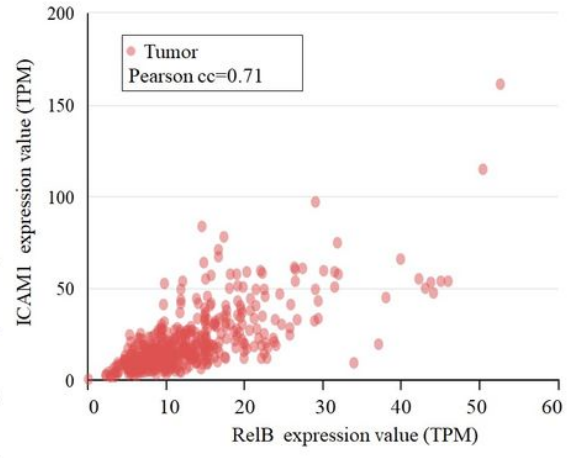

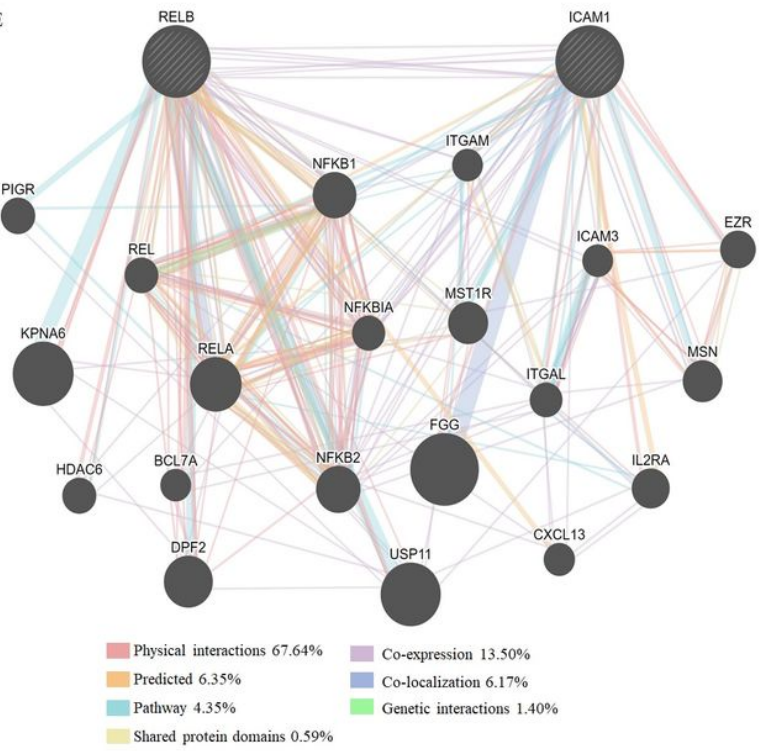

\section{Figure 4}

The correlation between RelB gene and ICAM1 gene in PC (UALCAN). (A) Heatmap showing the top 24 genes positively correlated with RelB in PC. The expression level of genes was shown as log2(TPM+ 1). (B) Scatter plot depicting the correlation between RelB and ICAM1 by Pearson correlation analysis, the Pearson cc was 0.71.(C) The comparison of RelB expression in normal samples and tumor samples by UALCAN database ( $p=9.023700 \mathrm{E}-03$ ). (D) The comparison of ICAM1 expression in normal samples and tumor samples by UALCAN database ( $p=9.963900 E-04)$. (E) The interaction network between RelB and ICAM1 in PC (GeneMANIA). 
A

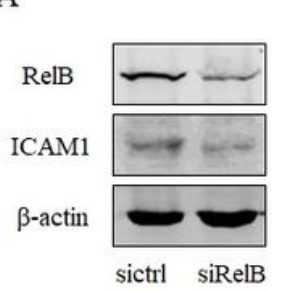

B

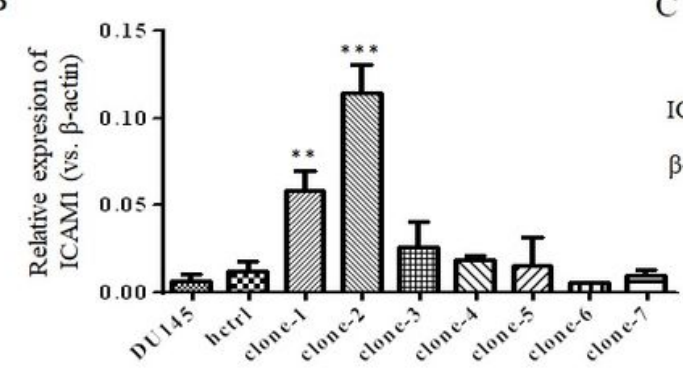

C

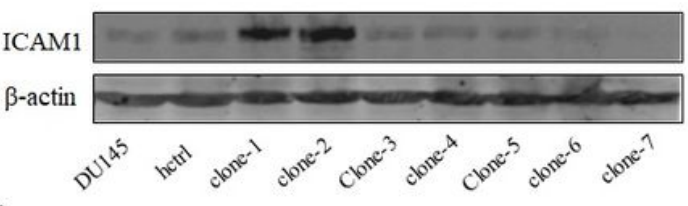

D

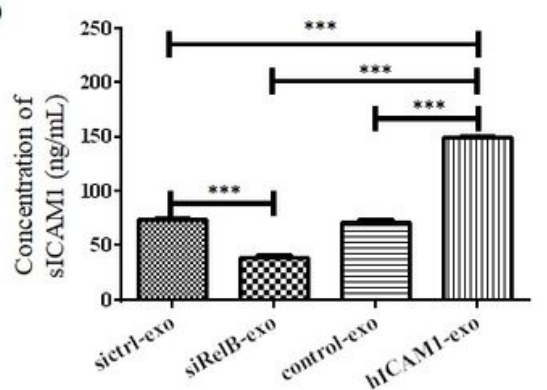

E

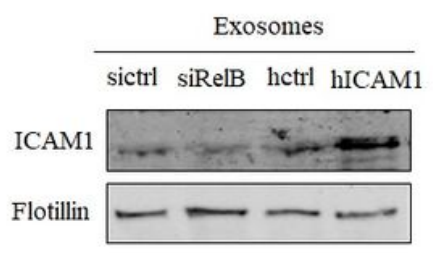

F

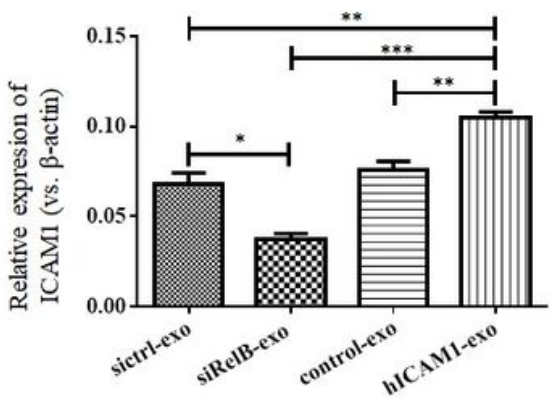

Figure 5

RelB and ICAM1 expression in DU145 cells or exosomes.(A)Protein expression of RelB and ICAM1 in sictrl and siRelB by western blotting. (B) The relative expression of ICAM1 mRNA in hctrl and different ICAM1-overexpressing clones by RT-qPCR. (C) Protein expression of ICAM1 in hctrl and different clones by western blotting. (D) The concentration of sICAM1, (E)protein, and (F) mRNA expression of ICAM1 in exosomes derived from sictrl, siRelB, hctrl, and hICAM1 cell lines by ELISA, western blotting, and qRT-PCR.

A

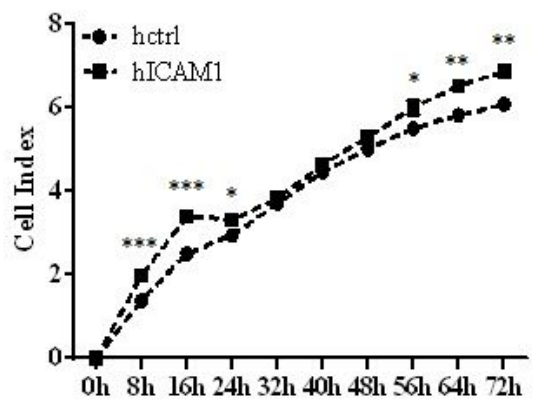

$\mathrm{D}$

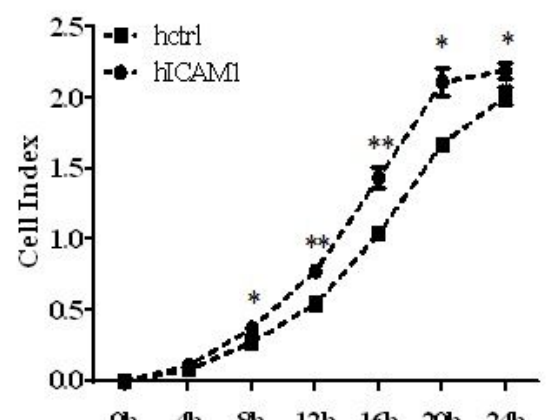

B

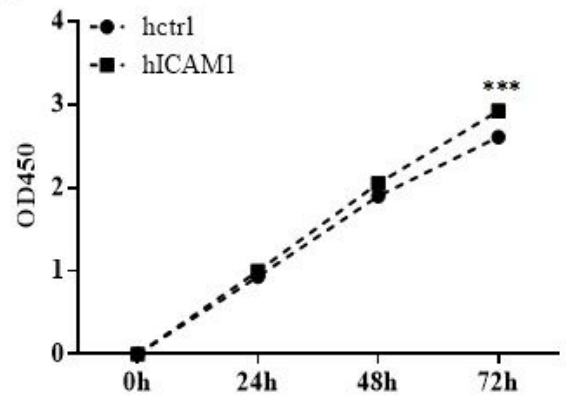

E

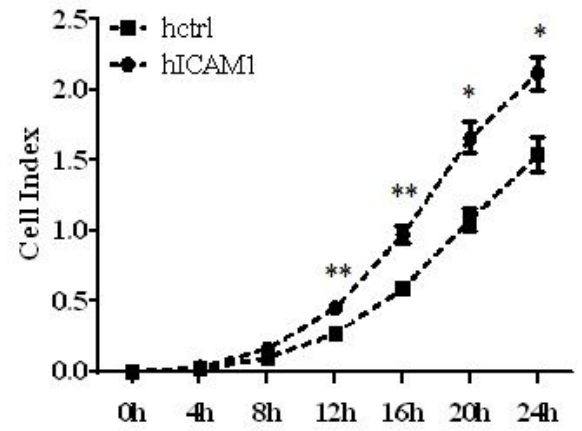

C

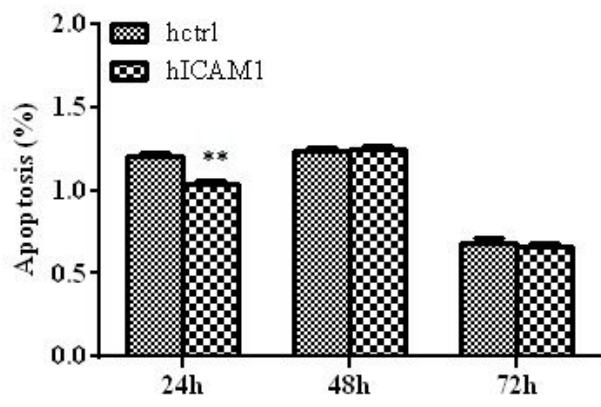

F

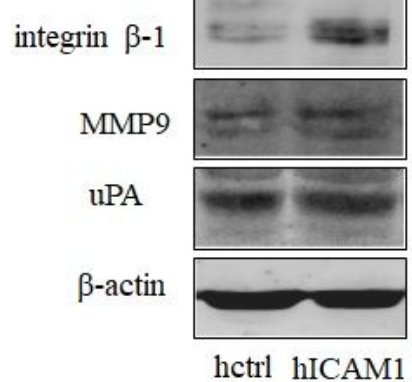


Carcinogenic characteristics of ICAM1 overexpressing DU145 cell line. (A) Cell growth assessmentbythe xCelligence RTCA instrument. (B)Cells viability evaluation by CCK-8 assay. (C) Early apoptotic cell proportion assessed by annexinV/PI staining. (D) Migration and (E) Invasion abilitiesassessedbythe xCelligence RTCA instrument.(F) Protein expressions of integrin $\beta-1$, MMP9, and uPA in hctrl and hICAM1 by western blotting.

\section{Supplementary Files}

This is a list of supplementary files associated with this preprint. Click to download.

- supplementarymaterialforcancercellinternational.docx 